\title{
DÜBLIN
}

Technological University Dublin ARROW@TU Dublin

\section{Recognizing Food as Part of Ireland's Intangible Cultural Heritage}

\author{
Máirtín Mac Con lomaire \\ Technological University Dublin, mairtin.macconiomaire@tudublin.ie
}

Follow this and additional works at: https://arrow.tudublin.ie/tfschafart

Part of the Food Science Commons

\section{Recommended Citation Life, 56:2, 93-115, DOI: 10.1080/04308778.2018.1502402 \\ This Article is brought to you for free and open access by the School of Culinary Arts and Food Technology at ARROW@TU Dublin. It has been accepted for inclusion in Articles by an authorized administrator of ARROW@TU Dublin. For more information, please contact arrow.admin@tudublin.ie, aisling.coyne@tudublin.ie, gerard.connolly@tudublin.ie.}

Máirtín Mac Con lomaire (2018) Recognizing food as part of Ireland's intangible cultural heritage, Folk

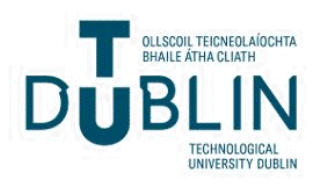




\section{Recognizing food as part of Ireland's intangible cultural heritage}

\section{Máirtín Mac Con lomaire}

To cite this article: Máirtín Mac Con lomaire (2018) Recognizing food as part of Ireland's intangible cultural heritage, Folk Life, 56:2, 93-115, DOI: 10.1080/04308778.2018.1502402

To link to this article: https://doi.org/10.1080/04308778.2018.1502402

册 Published online: 06 Aug 2018.

Submit your article to this journal $[\pi$

Шll Article views: 160

View Crossmark data \lceil 


\title{
Recognizing food as part of Ireland's intangible cultural heritage
}

\author{
Máirtín Mac Con lomaire (D)
}

School of Culinary Arts \& Food Technology, Dublin Institute of Technology, Dublin, Ireland

\begin{abstract}
Drawing on evidence from across a range of disciplines (literature, folklore, history, sociology, etc.), this paper explores the lack of an iconic link between Ireland and food, explaining the reasons why Ireland and food are not immediately linked in the popular imagination. It argues for recognition of foodways as a significant element in Ireland's intangible cultural heritage. It highlights and interrogates constructs, such as 'national' and 'regional' cuisines, charting the growing scholarship around Irish food history from the ground breaking work of A.T. Lucas and Louis Cullen to a recent emerging cluster of doctoral researchers. The paper identifies the potential in ideas of the Annales School for the study of Irish food history. Finally, it argues for a serious engagement with Irish language sources claiming that this Gaelic heritage can provide a competitive advantage in a new age of innovation and creativity.
\end{abstract}

\section{KEYWORDS}

Ireland; foodways; gastronomy; cultural heritage; UNESCO; food history; folklore

\section{Introduction}

Apart from costume, food and diet are among the most noticeable markers of cultural otherness within intercultural encounters. ${ }^{1}$ Anthropologists have long identified that our processing of food before ingesting marks us apart from other animals, ${ }^{2}$ with a leading British primatologist insisting that it was cooking that made us human. ${ }^{3}$ Bord Bia, the Irish Food Board, promotes Ireland internationally as 'The Food Island,' and their Food Wise 2025 programme plans to double Irish food exports to $€ 19$ billion by the year $2025 .{ }^{4}$ Fáilte Ireland has recently published its food tourism strategy where it notes that through its Food Strategy 2014-2016, it 'sought to shift the perception that Ireland is a producer of great ingredients to that of a nation with an authentic cuisine. ${ }^{5}$ Ireland has long been famous for its food but not necessarily for its cuisine or cooking. A.T. Lucas noted that Irish food displayed a remarkable continuity of tradition 'from the time of the earliest documentary evidence down to the widespread adoption of the potato in the late 17th century.' ${ }^{6}$ The American comedian Milton Berle once joked that Irish Gourmet Cooking was one of the four shortest books in history, but Colman Andrews, former editor of Gourmet Magazine disagrees, noting that 'no other nation in Western Europe - not even Italy or Spain - remains so intimately and pervasively 
connected to the land as Ireland does. ${ }^{, 7}$ Irish cuisine has been deemed by former Irish Times columnist Kevin Myers to be an oxymoron, and others have discussed it in less than glowing terms. ${ }^{8}$ Undoubtedly, influenced by colonial attitudes to the inferior other, this unenviable reputation, however, has been reversed in recent decades with Irish chefs and restaurants winning prestigious international awards. ${ }^{9}$ Growing research into Ireland's culinary heritage has also assisted in revealing a more balanced and nuanced story about our ancestors' dining habits and foodways. ${ }^{10}$ Despite its lacklustre fame, Ireland's culinary reputation has not suffered as severely as that of English cuisine. ${ }^{11}$ Among the issues this paper will discuss is whether the foodways and cuisine of one country can be considered as more valuable or sophisticated than that of another.

Drawing on multiple sources ranging from mythology, topography, literature, archaeology, food history, folklore, cookbooks and women's magazines, this paper will outline current thinking on food as an element of Irish cultural heritage, and provide a critical review of the literature on Irish food history to date. The paper intends to encourage food writers, scholars, chefs, educators and government agencies to recognize and celebrate food as part of Ireland's intangible cultural heritage. It will discuss the United Nations Educational, Scientific and Cultural Organization's (UNESCO) inclusion of food on their representation list of the intangible cultural heritage of humanity in 2010. It will discuss the growing scholarship on Irish food history, outlining how new techniques, archives, and sources are providing a clearer picture of this under-researched emerging discipline.

Finally, harnessing Fionnbarra Ó Brolcháin's ${ }^{12}$ argument that Ireland's lingering postcolonial shame regarding its heritage and traditions is counterproductive for the Irish economy, this paper argues for a serious re-engagement with Irish heritage. Irish language sources are highlighted as especially valuable to help historians and researchers paint a clearer and fuller picture of Ireland's culinary heritage. Vincent Morley notes how the refusal of so many historians to use sources in the Irish language has had a remarkable effect in how it 'consigned the bulk of the Irish people to the role of nonspeaking extras in the historiography. ${ }^{13}$ Declan Kiberd points out that it would be hard to imagine French people paying much heed to a history of their country written by someone with no working knowledge of its language; but they do (or did) these things differently in Ireland. ${ }^{, 14}$

\section{Food as cultural heritage}

The Oxford English Dictionary notes that the word 'heritage' derives from the Old French heritage, from hériter 'inherit,' and define it in a number of ways: (1) Property that is or may be inherited; an inheritance; (2) Valued objects and qualities, such as historic buildings and cultural traditions that have been passed down from previous generations; (3) Denoting or relating to things of special architectural, historical, or natural value that are preserved for the nation; (4) Denoting a traditional brand or product regarded as emblematic of fine craftsmanship; and (5) Denoting a breed of livestock or poultry that was once traditional to an area but is no longer farmed in large numbers. ${ }^{15}$ Food fits well into a number of these definitions, encompassing the long renowned cultural tradition of hospitality in Ireland, or the fine craftsmanship of the 
island's smoked salmon, butter or farmhouse cheeses. There has been growing interest in recent years in heritage breeds of Irish cattle, such as the Dexter ${ }^{16}$ or the Kerry cow, and in heritage breeds of potatoes, such as the 'lumper." ${ }^{\text {, }}$ There has also been a slow but gradual rise in the number of 'traditional' or 'heritage' foods and drink seeking Protected Designation of Origin (PDO) or Protected Geographical Indication (PGI) status from the European Union (EU). ${ }^{18}$ Whereas cows, potatoes, cheese, salmon or indeed whiskey are tangible products, Irish cuisine, meals, food traditions or food festivals belong to Ireland's intangible cultural heritage. Although they deal with tangible and consumable materials, the style and manner of consumption remain a part of intangible culture.

\section{Tangible heritage}

Since 1972, UNESCO has had a programme to protect the world's cultural and natural heritage, known as the World Heritage List, directed mostly to the protection and representation of tangible, monumental elements of past cultures or natural environment. Two Irish sites are currently listed: Brú na Bóinne - the Archaeological Ensemble of the Bend of the Boyne (1993) and Sceilg Mhichíl (1996). There are seven other Irish sites, shown below, on the tentative list since 2010, which highlight sites the State are currently considering for nomination ${ }^{19}$ :

- The Burren (2010)

- The Historic City of Dublin (2010)

- The Céide Fields and North West Mayo Boglands (2010)

- Western Stone Forts (2010)

- The Monastic City of Clonmacnoise and its Cultural Landscape (2010)

- Early Medieval Monastic Sites (2010)

- The Royal Sites of Ireland: Cashel, Dún Ailinne, Hill of Uisneach, Rathcroghan Complex, and Tara Complex (2010)

The Masterpieces of the Oral and Intangible Heritage of Humanity was initiated in 2001, as UNESCO's response to the call for humanity to widen its concept of cultural heritage by bringing in the intangible aspects, since the original World Heritage List excluded many Southern Hemisphere cultures, which did not produce monuments or other physical cultural manifestations. ${ }^{20}$

\section{Food as intangible heritage}

UNESCO defines oral and intangible heritage as 'the totality of tradition-based creations of a cultural community expressed by a group or individuals and recognized as reflecting the expectations of a community in so far as they reflect its cultural and social identity. ${ }^{21}$ Culinary traditions are among the many other forms of intangible heritage, which includes language, literature, music and dance, games and sports, rituals and mythologies, knowledge and practices concerning the universe, know-how linked to handicrafts, and cultural spaces. Intangible heritage is seen as a repository of cultural diversity, and creative expression, as well as a driving force for living cultures. UNESCO 
encourages communities to identify, document, protect, promote and revitalize such heritage since it can be vulnerable to forces of globalization, social transformation, and intolerance.

Between 2001 and 2005, UNESCO proclaimed 90 Masterpieces. This list was superseded in 2008 by the Representative List of the Intangible Cultural Heritage of Humanity. It took nearly a decade for culinary traditions to materialize and receive specific recognition. Since the first inclusion by UNESCO of food on its list in 2010 (France, Croatia, Mexico), however, there has been a growth of inscriptions by various countries concerning their food and drink related cultural traditions (Table 1). It is interesting to note that certain countries, such as Croatia are well represented on the list, particularly for their size, while others fail to appear at all. In 2017, Ireland appeared on the list for the first time when the musical practice of Uilleann piping was inscribed on the UNESCO list of the intangible cultural heritage of humanity. ${ }^{22}$

\section{Protecting geographical foods: AOCs, PDOs and PGIs}

Certain countries and regions of the world are renowned for specific food and beverage traditions and products - for example Sushi (Japan), Parma Ham (Italy), Champagne (France). In France, Roquefort cheese was regulated by Parliamentary decree in 1411, and became the first French cheese to be awarded an Appellation d'Origine Contrôlée (AOC) in 1925. The AOC of French wine was set up in 1935 based on the concept of

Table 1. Food and drink related cultural traditions enshrined by UNESCO.

\begin{tabular}{|c|c|c|}
\hline Year & Country & List of elements \\
\hline 2010 & Mexico & $\begin{array}{l}\text { Traditional Mexican cuisine - ancestral, ongoing community } \\
\text { culture, the Michoacán paradigm }\end{array}$ \\
\hline 2010 & Croatia & Gingerbread craft from Northern Croatia \\
\hline 2010 & France & Gastronomic meal of the French \\
\hline 2013 & Turkey & Turkish coffee culture and tradition \\
\hline 2013 & Georgia & Ancient Georgian traditional Qvevri wine-making method \\
\hline 2013 & Belgium & Shrimp fishing on horseback in Oostduinkerke \\
\hline 2013 & $\begin{array}{l}\text { Cyprus - Croatia - Spain - Greece - Italy - } \\
\text { Morocco - Portugal }\end{array}$ & Mediterranean diet \\
\hline 2013 & Korea & Kimjang, making and sharing kimchi in the Republic of Korea \\
\hline 2013 & Japan & $\begin{array}{l}\text { Washoku, traditional dietary cultures of the Japanese, notably } \\
\text { for the celebration of New Year }\end{array}$ \\
\hline 2014 & Armenia & $\begin{array}{l}\text { Lavash, the preparation, meaning and appearance of traditional } \\
\text { bread as an expression of culture in Armenia }\end{array}$ \\
\hline 2015 & Democratic People's Republic of Korea & $\begin{array}{l}\text { Tradition of kimchi-making in the Democratic People's Republic } \\
\text { of Korea }\end{array}$ \\
\hline 2015 & Namibia & Oshituthi shomagongo, marula fruit festival \\
\hline 2015 & $\begin{array}{l}\text { United Arab Emirates - Saudi Arabia - } \\
\text { Oman - Qatar }\end{array}$ & Arabic coffee, a symbol of generosity \\
\hline 2016 & Tajikistan & $\begin{array}{l}\text { Oshi Palav, a traditional meal and its social and cultural contexts } \\
\text { in Tajikistan }\end{array}$ \\
\hline 2016 & $\begin{array}{l}\text { Azerbaijan - Iran (Islamic Republic of) - } \\
\text { Kazakhstan - Kyrgyzstan - Turkey }\end{array}$ & $\begin{array}{l}\text { Flatbread making and sharing culture: Lavash, Katyrma, Jupka, } \\
\text { Yufka }\end{array}$ \\
\hline 2016 & Belgium & Beer culture in Belgium \\
\hline 2017 & Italy & Art of Neapolitan 'Pizzaiuolo' \\
\hline 2017 & Azerbaijan & $\begin{array}{l}\text { Dolma making and sharing tradition, a marker of cultural } \\
\text { identity }\end{array}$ \\
\hline 2017 & Malawi & Nsima, culinary tradition of Malawi \\
\hline
\end{tabular}


'terroir,' meaning the complete natural environment, including factors, such as the soil, topography, and climate, in which a particular wine is produced.

A European system for the protection of the geographical names of certain foodstuffs (which have a tangible link to the geographical area after which they are named) was established by Council Regulation 1151/2012. Protection under the system is absolute and extends to translations of the name, evocation, misuse or imitation. ${ }^{23}$ Ireland has a number of active PDO's and PGI's - Connemara Hill Lamb; Imokilly Regato Cheese; Oriel Sea Salt; Oriel Sea Minerals, and the Waterford Blaa/Blaa. There is potential for more - applications for Sneem Black Pudding and Wexford Blackcurrant(s) have been submitted to the European Commission following national consultation. However, the group approach favoured by the Regulations and the restrictions on including a member State's name in the PDO/PGI have contributed to limited interest in Ireland. From the perspective of alcoholic spirit drinks, the rules are slightly different since $2008 .^{24}$ This geographical indication identifies a spirit drink as originating in the territory of a country, or a region or locality in that territory, where a given quality, reputation or other characteristic of that spirit drink is essentially attributable to its geographical origin. Irish Products included in the Legislation includes (1) Irish Whiskey/Uisce Beatha Éireannach/Irish Whisky; (2) Irish Cream; (3) Irish Poteen/ Irish Poitín. Ireland has historically been more associated with drink than with food. Colman Andrews notes that 'no sane person ever questioned the quality of Irish stout or whiskey' but that apart from Irish stew and soda bread, most outsiders did not know what the Irish ate. National stereotypes of Irish cuisine were apparent in jokes, such as that a seven course dinner in Ireland was a potato and a six pack of Guinness. ${ }^{25}$

\section{Regional cuisines, national cuisines or the cuisine of empires}

Similar to the AOC system, food fits better within a regional system than a national system. The concept of national cuisines is relatively recent and has generated a literature of its own. ${ }^{26}$ In this context Italian cuisine is an interesting case study. ${ }^{27}$ Italian cuisine has achieved global popularity, but does such a thing exist? Italian unification or the Risorgimento was not completed until 1871, although it began with the Congress of Vienna (1815). Italian food is really a combination of various regional foods based around the original city states and even further based on the more local concept of campanalismo ${ }^{28}$ - symbolizing a sense of identity, of pride, and of belonging to the place of your birth, a feeling that is usually much stronger to an Italian than any sense of national identity. Rachel Laudan argues that empires are a more suitable lens by which to explore cuisine than nations and notes that one of the most influential empires was the Christian empire, which dominated all of Europe, including Ireland, for so long. ${ }^{29}$

Scholars agree that national cuisines rely on texts for their authentication. ${ }^{30}$ Pellegrino Artusi's La scienza in cucina e l'arte di mangiar bene (The Science of Cooking and the Art of Fine dining), published in 1891, helped develop Italian national cuisine, as it introduced dishes from the South to the North and vice versa. It is also widely understood that François Pierre La Varenne's (1651) La Cuisinier François represents the first codification of a distinctive French cuisine. Until relatively recently, French haute cuisine was the hegemonic model favoured by a pan-European élite, and 
evidence of this cuisine is found in both Irish and other European literature. ${ }^{31}$ Irish missionaries began a long and steady connection between Ireland and France, and indeed throughout Europe based on religion, education and trade. ${ }^{32}$ The appearance of three recipes specifically 'in the Irish style, ${ }^{33}$ included in Lancelot de Casteau's (1604) cookbook Ouverture de cuisine, published in Liège, may be explained by noting the author had previously served as master cook to three 16th century prince-bishops and their possible relationships with Irish missionaries. ${ }^{34}$ On commencing his viceroyalty, the Duke of Rutland (1784-1787) dispatched the chief cook of Dublin Castle to France to expand his culinary repertoire by completing 'stages' at French royal courts, such as the renowned gourmets, the Franco-Irish Bishop of Narbonne, Arthur Richard Dillon, and the Duc d'Orléans. ${ }^{35}$ Although apparently selective, as examples these both confirm that transmission of culinary knowledge and practices between countries, nations, and regions has a long history and that information flowed in both directions.

What about the situation where culinary knowledge and traditions remained oral and were not preserved in text? Arjun Appadurai describes the construction of a national cuisine in India as being a postcolonial, post-industrial process. ${ }^{36}$ Following this lead, Dorothy Cashman explains why there are no recorded recipes from sources that could be considered native Irish or Gaelic in the Irish manuscripts cookbooks associated with the Big Houses in Ireland that she researched. ${ }^{37}$ Appadurai argues that 'if we take the long view of Hindu thought, which has left ample textual deposits, it is possible to assert that while gastronomic ( $\mathrm{sic}$ ) issues play a critical role, culinary (sic) issues do not. ${ }^{38}$ While copious records exist about the immense amount of food that was consumed, little is recorded in the Hindu tradition about how it was cooked. This absence extends across legal, medical and philosophical texts; while there is an amount of information regarding taboos, prescriptions and injunctions concerning food, there are no recipes: - 'the processes that transform ingredients into dishes are invariably offstage. ${ }^{39}$ This is equally true to Ireland where Cashman confirms that apart from a handful of texts, the growth of Irish authored cookbooks runs nearly in parallel with the foundation of the State in $1922 .{ }^{40}$

\section{Irish food tradition or national Irish cuisine - does it exist?}

In an Irish context, it is probably more reasonable to discuss the concept of regional cuisines which are influenced by geography, climate, religion and tradition. Myrtle Allen, ${ }^{41}$ of the renowned Ballymaloe House, Co. Cork, has noted that in Ireland we belong to a 'geographical and culinary group with Wales, England and Scotland as all countries share traditions with their next door neighbours. ${ }^{\prime 2}$ This could also account for the difficulty of creating a 'national' cuisine. During the Celtic revival in the late 19th century, nobody thought of food culture as an element in nation building. Literature, folklore, music and drink were considered, but food remained outside that list of chosen 'national' categories. The relatively modern concept of 'national' food, therefore, presents certain difficulties of definition in an Irish context, the island having gained independence only in 1922. Yet, similar to Pellegrino Artusi's book in Italy, a number of Irish authored and Irish centred cookbooks appeared in the following decades. ${ }^{43}$ Vincent Morley notes, however, that Catholicism and national identity were linked explicitly in the early 1600s; and much to the surprise of both republicans 
and revisionist, that it was then (and not in the 19th century) that the word 'náisiún' or 'nation' began to appear. ${ }^{44}$ Central to his argument is the contention that the version of the Irish past propounded in early modern literary Irish by Seathrún Céitinn in Foras Feasa ar Éirinn (1634-5) ${ }^{45}$ - a Catholic people, whose lineage survived Norse and subsequent depredations - was disseminated in less elevated language by rhymesters and songsters, principally in the oral tradition. ${ }^{46}$ From its arrival in the 5th century, Christianity has influenced the dining patterns of the Irish. The observance by the early Irish church of fast and abstinence is apparent in the Irish names for Wednesday, De Cétaín/De Ceadaoin or 'first fast' and Friday, Aín dídine/De Aoine, or 'last fast. ${ }^{47}$ The four quarterly feasts of the old Irish year, Imbolc (1st February), Beltaine (1st May), Lughnasa (1st August) and Samhain (1st November) gradually yielding to Easter and Christmas, with St Brigid's day seeking to supplant Imbolc and St Martin's day seeking to supplant Samhain. The old Irish festivals and patterns with many of their associated traditions, including foodways, have remained remarkably strong. ${ }^{48}$ From Easter eggs, roast lamb, geese, turkeys and plum pudding, to roast beef, colcannan and barm brack, each festival has its associated food heritage and tradition, even if the rigorous regimen of fasting and abstinence of pre-Second Vatican Council Catholicism is a fading memory to those old enough to remember Pope Paul VI issuing Paenitemini (1966). ${ }^{49}$

Cashman highlights this sharing of traditions between the island of Ireland and its nearest neighbours 'that are rooted through and beyond historical contingency.' She notes Tom Jaine's discussion of the English kitchen where he criticizes those commentators who malign English cookery and deny its existence, 'that by dint of its derivative and imitative character it has lost all claim to discrete identity.' Jaine argues the absurdity of this claim, noting that 'if English people cook, the product must be English cookery. ${ }^{50}$ Cashman similarly proposes that if Irish people cook, in whatever way the term 'Irish' is construed, the same argument holds true, although now in the context of globalization, that narrative becomes somewhat more complex. Unlike France or Italy, where distinctive differences characterize the food eaten in the north and south of both those vast countries, the climate and regional food of the British Isles does not vary dramatically. Nevertheless, some regional specialties do exist and writers often use reference to these to locate a character within a certain context. Maura Laverty exhibited this to good effect in her novel Never No More:

I always looked forward to Shrove Tuesday and to Gran's pancakes, which were not made in the Kildare way with an ordinary batter of milk and eggs and flour. She made them as they make them in the West of Ireland, with grated raw potato. She got her recipe for boxty potatoes from her mother who was a Mary Kelly from Galway.... The boxty pancakes were crisp little crumpet-like cakes that were eaten hot with butter and sugar as they came from the pan. Shrove Tuesday was unthinkable without boxty-on-the-pan. They were the fortunetellers that gave you a glimpse of what the coming year held for you. $^{51}$

Laverty's description, published in the mid-20th century, highlights regional variations of foodstuffs within the island of Ireland, such as Farls, Boxty, Blaa, Ballach Buí (Salted Ballan Wrasse), Drisheen, Coddle, or Yellowman (see Figures 1 \& 2). Many of these dishes and other, such as Colcannan, Steaimpí, Gingerbread, Sugar Sticks (or Peggy's Legs) are also found in poetry and songs from the Irish tradition. ${ }^{52}$ The flavour principles of ginger and caraway are abundantly evident in the baked dish traditions 


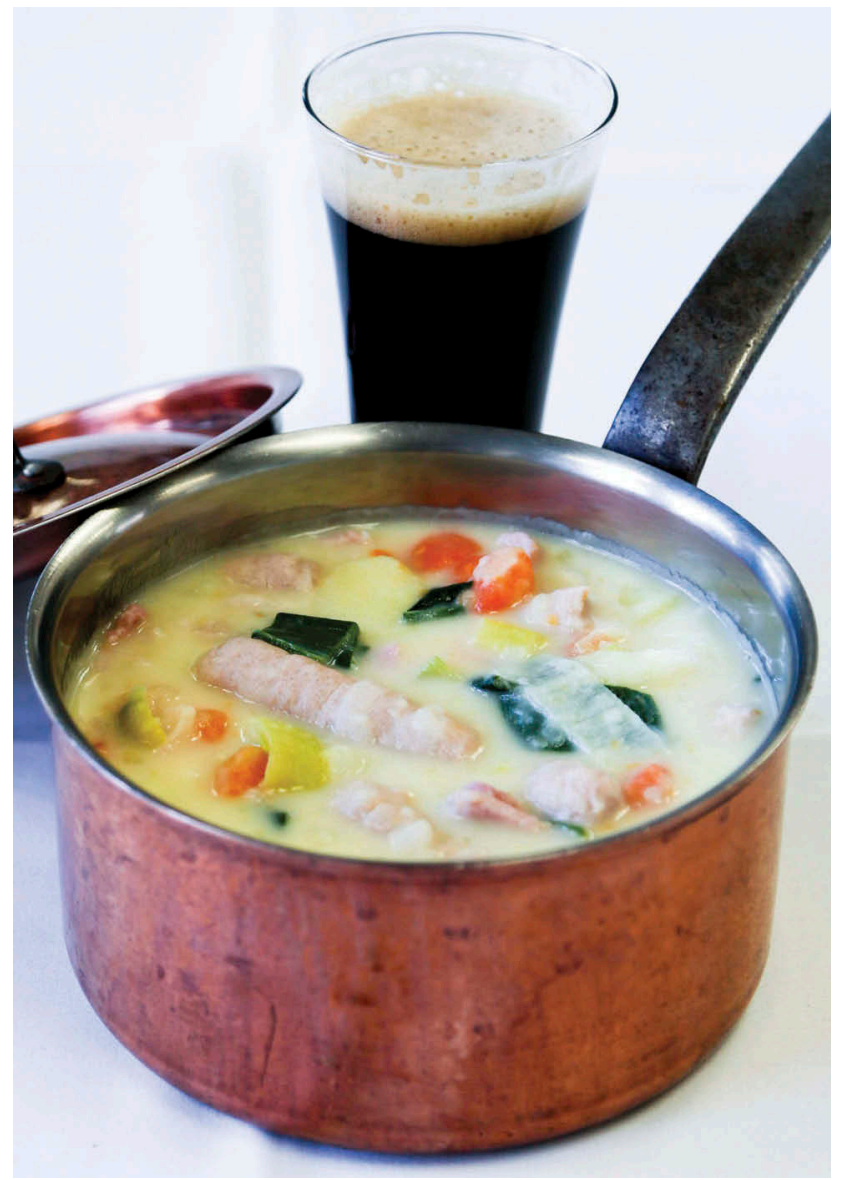

Figure 1. Dublin Coddle - One Pot Stew using Sausages and Bacon.

of Ireland and Gingerbread appears in multiple sources. ${ }^{53}$ Blaa is to this day associated with Waterford, Coddle with Dublin, Drisheen with Cork, Periwinkles (see Figure 7) with Kilkee, County Clare and Yellowman with the Auld Lammas Fair in Ballycastle, County Antrim.

\section{Irish food hidden in plain sight}

It is said that we don't appreciate what we have until it's gone. Research by the company Denny's sausages found that half of Irish people surveyed had brought sausages with them in their luggage to a foreign country at least once in their life. ${ }^{54}$ Travellers from Ireland only realize that the varieties of sausages, bacon, tea, crisps, butter, milk, chocolate, bread, biscuits, sweets and many other food items that they take for granted cannot be widely purchased abroad. Cathal Cowan and Regina Sexton undertook the Irish part of a European research project seeking to categorize and document traditional foods across Europe. Some of the more unusual foods they categorized as Irish were commercial 


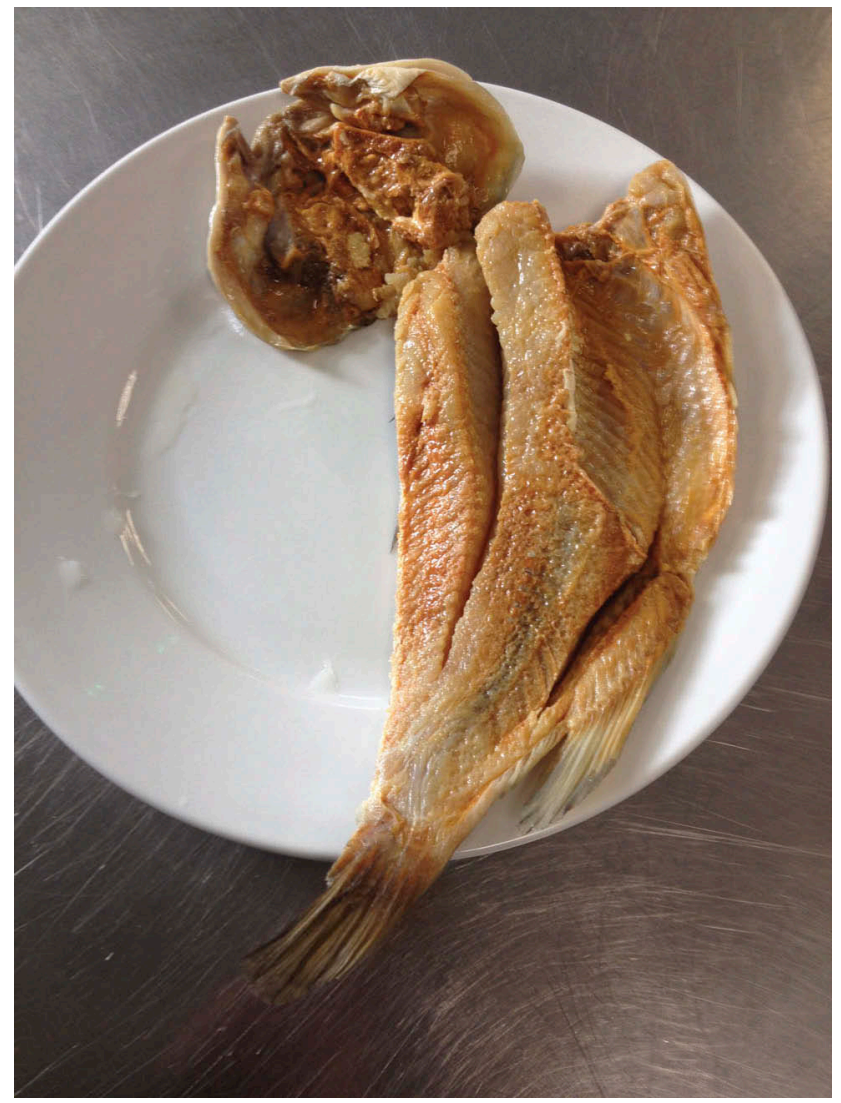

Figure 2. Ballach Buí - Salted Ballan Wrasse.

products Kimberley, Mikado and Coconut Cream biscuits, clove rock and apple drops (boiled sweets), alongside the more traditional boiled bacon and cabbage and Irish stew. ${ }^{55}$ Bord Bia's 'What Ireland Ate Last Night' study found that Ireland's favourite style of dinner in 2011 was a classic 'meat and two veg' which accounted for almost 1 in 6 of the previous night's dinners. In fact, 6 in 10 people in Ireland had consumed a classic meat and two veg dinner in the previous week. The survey found that age-old traditions were firmly ingrained in our evening meal choices, with fish consumption peaking markedly on a Friday. Meat and two veg and specifically roast beef dominated the Sunday menu, although roast chicken dinners and spaghetti bolognaize topped the poll of specific dishes mentioned. Diners consumed potatoes in $40 \%$ of all the previous nights' evening meals, not including chips or wedges which featured in a further $16 \%$ of meals. In fact the survey found that almost 8 in 10 Irish people had eaten potatoes with dinner at least once in the previous week. ${ }^{56}$ This confirms quite a conservative trend in Irish eating habits, adhering to traditional Irish dishes and cuisine, despite the rise of globalization and increased availability of foreign foods. 


\section{Dissenting voices}

There are still some commentators who until recently advocated that Ireland did not have a food culture and that the term 'Irish cuisine' was oxymoronic. ${ }^{57}$ Hasia R. Diner suggests in her monograph Hungering for America: Italian, Irish and Jewish Foodways in an age of Migration ${ }^{58}$ that Ireland failed to develop an elaborate national food culture, and that unlike those of other peoples, 'Irish writers of memoir, poems, stories, political tracts, or songs rarely included the details of food in describing daily life.' She also notes that those who observed them or recorded Irish voices rarely represented them as wanting to eat better or craving particular items. Diner's thesis is based on a selection of writings particularly associated with the Celtic revival at the end of the 19th century, ${ }^{59}$ an era in which Irish people were encouraged to learn and speak the Irish language, give their children Irish names, play Irish music, and dress in the manner of the Irish. The fact that they were not encouraged to eat Irish food is not evidence of its inexistence, as Diner argues, but that they had already been eating Irish food, which was unremarkable because of its similarity to English, Welsh or Scottish, in other words, British food. Without the capacity to emphasize Irish difference and distinctiveness, food could not be appropriated as a means to promote cultural and political independence. Diner's argument also overlooks a long tradition of hospitality, and of using descriptions of food in songs and poetry to satirize lack of hospitality as in the Middle Irish tale 'Aislinge Meic Con Glinne' (12th century), for example, in Antaine Ó Raiftearaís (1784-1835) poem 'Bainis ar an tS'leacháin Mhóir. ${ }^{60}$ It also ignores a long tradition described by Katharine Simms as 'guesting and feasting,' whereby the Brehon Law tracts outlined various legal rights to hospitality in Ireland, or where hosts voluntarily issued invitations to a feast. ${ }^{61}$ Diner's argument similarly indicates her lack of awareness of texts, some in the Irish language, such as Cín Lae Amhlaoibh by Amhlaoibh Ó Súilleabháin, of Callan, Co. Kilkenny; Retrospections of Dorothea Herbert 1770-1806; The diary of Nicholas Peacock; The Synge Letters; or Society and Manners in nineteenth century Ireland, which contain numerous food references. ${ }^{62}$ Kerby Miller notes that John Gamble's accounts of his travels are unusually rich and remarkably free of both sectarian and class prejudice, and that his knowledge of the Irish language also made him an especially acute observer of life among the poor inhabitants of Ulster's mountains. ${ }^{63}$

\section{Irish language sources}

The French 'histoire des mentalités' describes a particular way of researching and writing history principally associated with the Annales School. Theodore Zeldin's five-volume masterpiece A History of French Passions (1973-1977), which described private emotions, instead of a narrative of public events, contains a 17,000 word chapter on food and drink in France. ${ }^{64}$ Although the French have long studied mentalities, Irish historians have concentrated more on high politics focusing on archival documents left by the 'winners of conflicts.' In Ireland, 'tradition' - how ordinary people remembered things (including language, food, and much of our heritage) - has been left to the folklorists, and is often disseminated via the oral tradition. The ground breaking work of folklorists, such as Henry Glassie, Estyn Evans, Caomhín Ó Danachair, Bríd Mahon 
and Patricia Lysaght on food must be acknowledged. ${ }^{65}$ Vincent Morley notes how the failure of so many historians to use sources in the Irish language had a remarkable effect on our official history. ${ }^{66}$ Declan Kiberd points out the absurdity of a history of any country written by someone with no working knowledge of its language. Kiberd argues that the narrowly linguistic focus in University Irish Departments tended towards a neglect of the content. One clear exception to this observation was Breandán O Buachalla, whose book Aisling Ghéar set the precedent for Vincent Morley's The Popular Mind in Eighteenth-century Ireland as the most radical remapping of Irish Studies to appear in the past 30 years. ${ }^{67}$

From an Irish food heritage perspective, although scholarship in the field is growing in recent years, ${ }^{68}$ Irish language sources still remain neglected and underused. ${ }^{69}$ The food 'motif can be found throughout these texts from earliest times, from the dinnseanchas $^{70}$ (placename lore), Irish mythology, to the goliardic poetry of the medieval monks, through to the bardic poetry of Gaelic Ireland prior to the Flight of the Earls (1607). From the ancient pagan Gaels, converted by Christian missionaries (5th century), raided and eventually settled by Vikings (9th century), Norman barons (12th century), prior to annexation by the English crown and finally, military and cultural defeat of the Gaelic order by that same English power (16th century), food appears as a constant motif in their myths, sagas, stories, songs and poetry. Writers, such as Jonathan Swift and William Butler Yeats (through Lady Gregory's translations in the latter's case) were well-versed in this Irish language tradition of poetry and mythology drawing from it within their work. One such example is Swift's translation of Aodh Mac Gabhráin's Pléaráca na Ruarcach (The Revelry of the O'Rourkes) about a famous banquet held by a Leitrim chieftain in the 16th century: 'O'Rourke's noble fare/Will ne'er be forgot/By those who were there/Or those who were not./His revels to keep,/we sup and we dine/on seven score sheep, Fat bullocks and swine. ${ }^{71}$

The diet of the Irish has been continuously changing, adapting and drawing influence from its neighbours, trading partners, invaders and the overarching influence of the Christian church/empire, ${ }^{72}$ which is firmly evident in the dinnseanchas, the genre of early Irish literature, recounting the origins of place-names and traditions through associated events and characters. Food related place-names range from Cluain Meala (Figure 4) (Honey Meadow - Clonmel) in County Tipperary to Léim an Bhradáin (Salmon Leap/Lax Leap - Leixlip) in County Kildare, Scairbh na gCaorach (shelf of the Sheep) - Emyvale, Co. Monaghan (Figure 3) to the more evocative Cuas Rinn an Aonbhallaigh (Cove of the point of the solitary wrasse - Coosrinaneanwallig) in County Kerry. ${ }^{73}$ Predominantly of Gaelic origin, some food-related Irish place-names also have Viking, Norman or English connections. ${ }^{74}$ Many Irish people have little or no knowledge of the richness and variety of their ancestors' diet - which included wild garlic, honey, grouse, game, white meats or bánbhia (milk, buttermilk, curds etc.), eels, wrasse, oats, rye, gruel, pottage, watercress, apples, hazelnuts, bilberries, sorrel, tansy, and edible seaweed (see Figure 6) - prior to the arrival of the potato, all of which feature in Ireland's place-names. Similar to the watercress eaten as a fresh meal in the old Irish tale Buile Shuibhne, certain seafood (cockles and dogfish) were considered 'poor man's food.' This is reflected in the 17th century poet Aogán Ó Rathaille's lament for the days of his youth before the Battle of the Boyne in 1690, after which his Jacobite patron's lands were confiscated and the poet and his family found themselves 


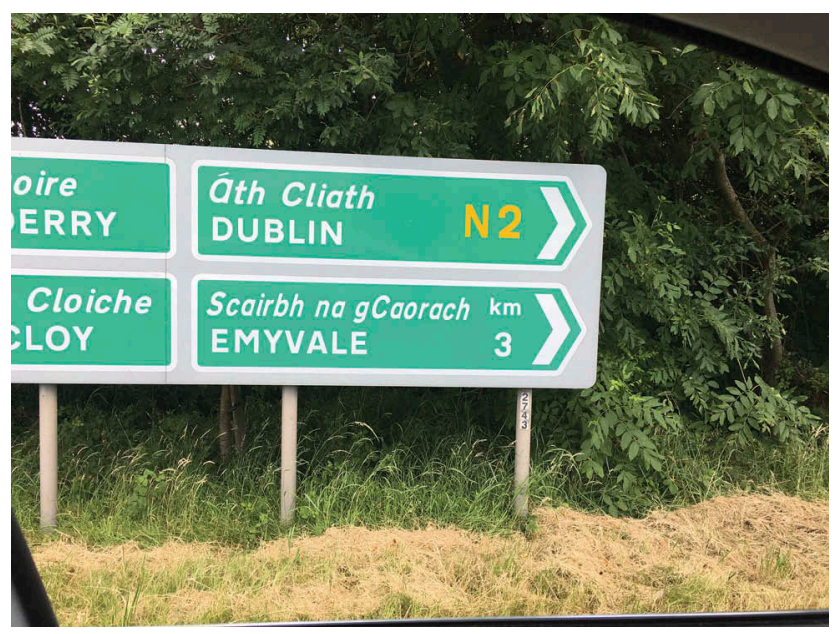

Figure 3. Scairbh na gCaorach - Emyvale, Co. Monaghan Road Sign.

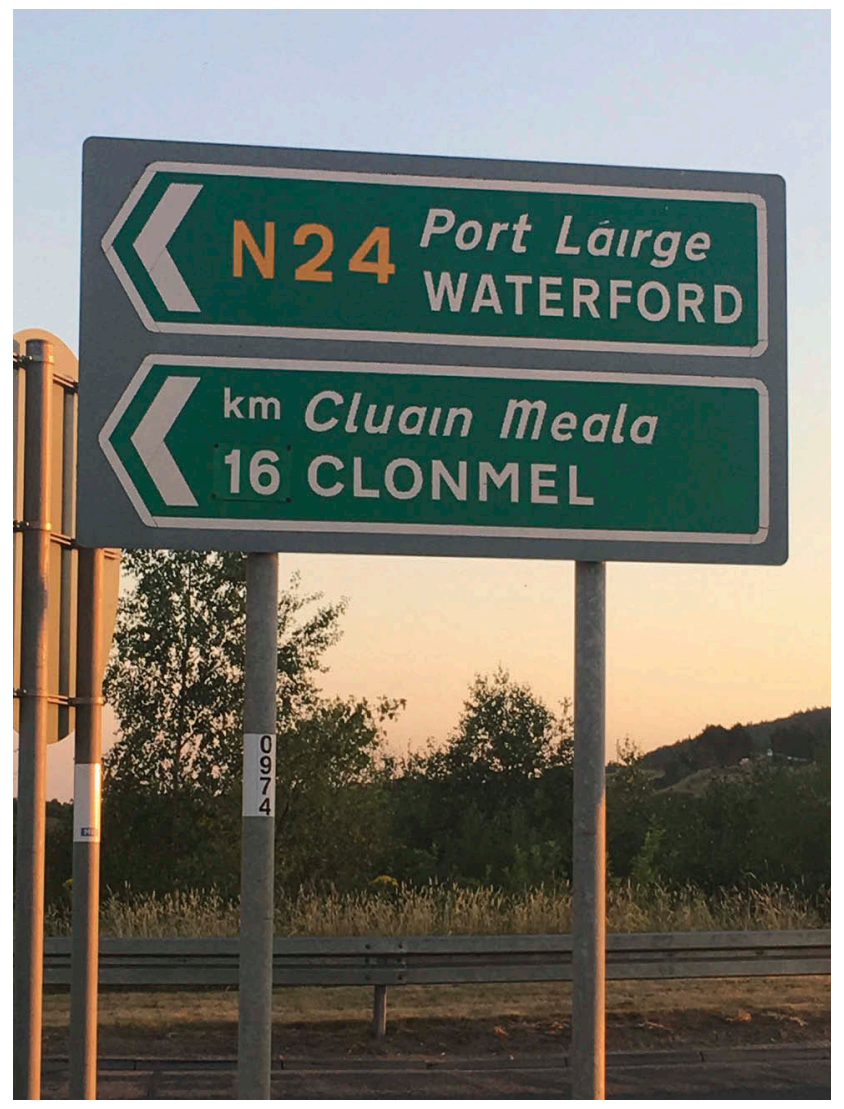

Figure 4. Cluain Meala Honey Meadow - Clonmel, Co. Tipperary Road Sign. 
dispossessed. In his poem 'Is fada liom oíche fhiorfhliuch', he notes that he had never experienced eating the food of the poor in his youth, in contrast to the aristocratic food of his patron. ${ }^{75}$ The wealth of food descriptions and similes in the pre-famine songs of Raiftearaí are worthy of a study all of their own. ${ }^{76}$ An outstanding example of an epic food song/poem of the 19th century is Raiftearaís 'Bainis an tS'leacháin Mhóir,' a satire of a wedding to which the poet was not invited, where the poor couple had as a wedding breakfast only potatoes and salted herrings. ${ }^{77}$ It comprises 11 stanzas outlining the food and drink served at the banquet, including material culture. Seven types of meat and poultry, eight game birds, 15 finfish, five shellfish, cakes and yeast bread are listed. Drinks include ale, porter, whiskey, punch, brandy, rum, madeira and negus. White dishes, pewter plates, sharp knives, skewers, delft, china, tureens, teapots, white and speckled dishes, jars, tankards, glasses, tables, table cloths are described. The wedding turns into a mighty battle, however, with collected beggars spilling blood with cudgels. ${ }^{78}$ Contemporary famine-related songs have been identified and discussed by Cormac Ó Gráda, but the Great Famine greatly curtailed the strong oral tradition of storytelling, songs and music that had been so vibrant particularly in the Irish speaking districts in their 'clachán'-based communities along the western Atlantic seaboard. ${ }^{79}$ Storytelling continued in the West where pre-Famine patterns lasted for another two generations until the Irish Folklore Commission was able to collect much of it, and assemble one of the world's largest folklore collections. ${ }^{80}$ The Schools' Collection (1937-8) has been digitized by the National Folklore Collection in UCD and provides numerous food related stories as seen in the entry for Baile Scadáin (Herring Town/ Balscadden) in County Dublin (Figure 5).

There has also been a tendency among commentators (particularly travellers' accounts) to present discussions about food in Ireland before the famine in a binary fashion (wealthy or poor). ${ }^{81}$ Against this, Tomás de Bhaldraithe in the introduction to Cín Lae Amhlaoibh notes the vivid descriptions in Humphrey O' Sullivan's diary of the fine meals of the middle classes that disproves claims that the Irish speaking natives did not have a varied diet or were not proficient in the art of cookery. ${ }^{82}$ Scholars from a diversity of disciplines (archaeology, history, sociology, folklore, linguistics, literature, architecture, drama, business, art and design) are currently engaging in research on Ireland's food heritage, which highlights the transdisciplinary nature of gastronomy and food studies. This paper encourages them to engage with source material in the Irish language and to embrace our oral heritage, mythology and folklore to furnish a more dynamic and creative lens to their analysis.

\section{Discussion and conclusions}

As previously highlighted, apart from costume, food and diet are among the most noticeable markers of cultural otherness within intercultural encounters. ${ }^{83}$ Krishnendu Ray notes that 'nothing devalues a cuisine more than proximity to subaltern others, ${ }^{84}$ which may explain how, up until recently, the concept of 'Irish Cuisine' was considered by some to be something of a contradiction in terms. Things are changing dramatically concerning food in Ireland. Irish food is seen by state bodies as a driver of economic development, with Bord Bia promoting the country as 'The Food Island' and Fáilte Ireland's new vision for food tourism being that 'Ireland will be recognized by visitors 


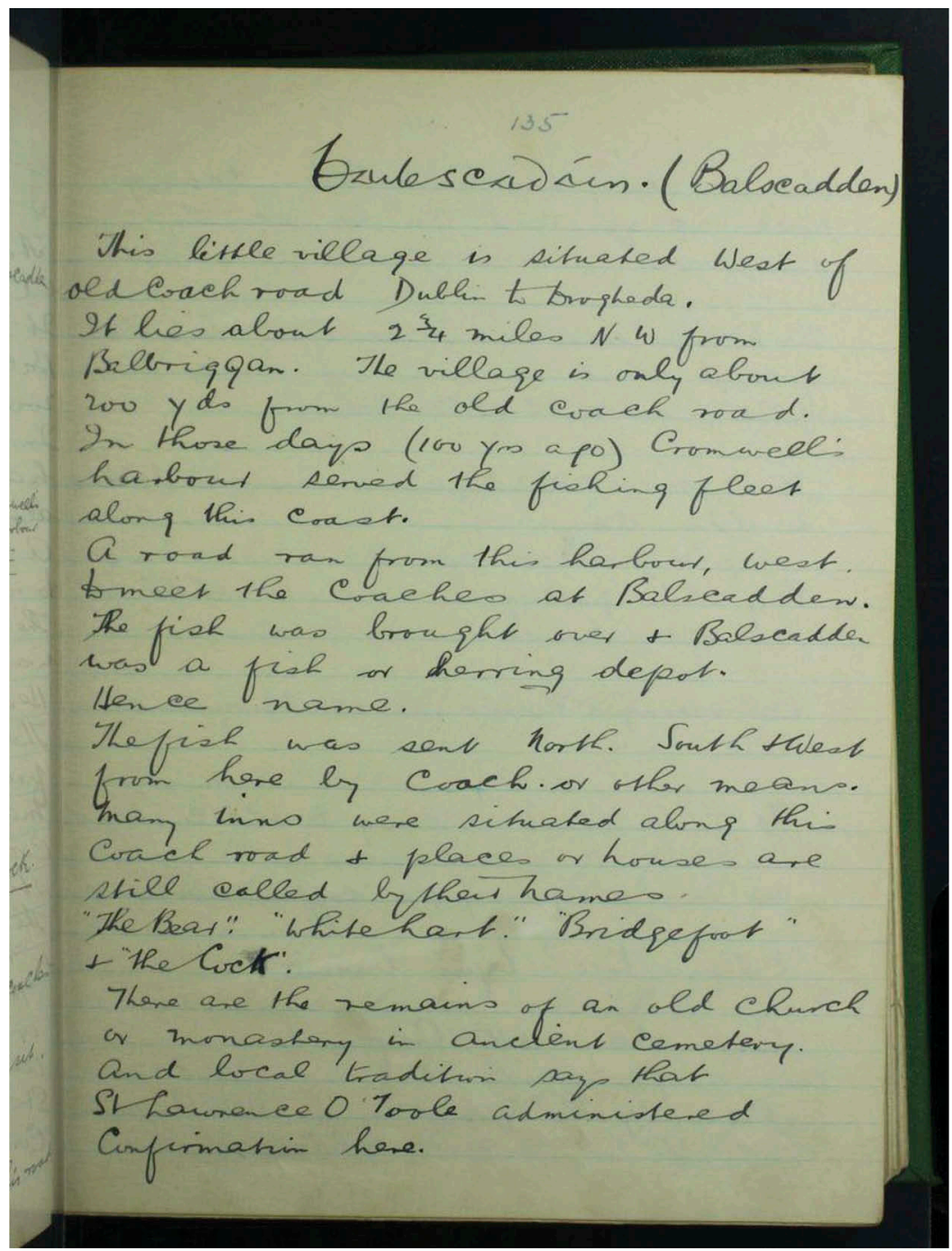

Figure 5. Balscadden Herring Town Entry in NFC School's Collection 1937-8, courtesy of NFC, UCD. See www.duchas.ie

for memorable food experiences which evoke a unique sense of place, culture and hospitality. ${ }^{85}$ In the past, because of its associations with the domestic and the diurnal, Irish food was thought far too quotidian to be valued, particularly when contrasted to the professional, modernism and exoticism associated with French haute cuisine. William Wilde's well known 1854 essay The Food of the Irish argued that the potatoconsuming pre-Famine poor essentially subsisted on raw food, their roasted and boiled potatoes failing to qualify as cooked fare, compared to those with fine palates, who desire 'pommes a la crème,' making them 'modern. ${ }^{86}$ The hegemony of French haute cuisine, however, has been receding somewhat in recent years, being superseded by a new aesthetic that values local, seasonal, traditional and sustainable food - best illustrated by the New Nordic Food Movement. Many Irish chefs contributed to the 


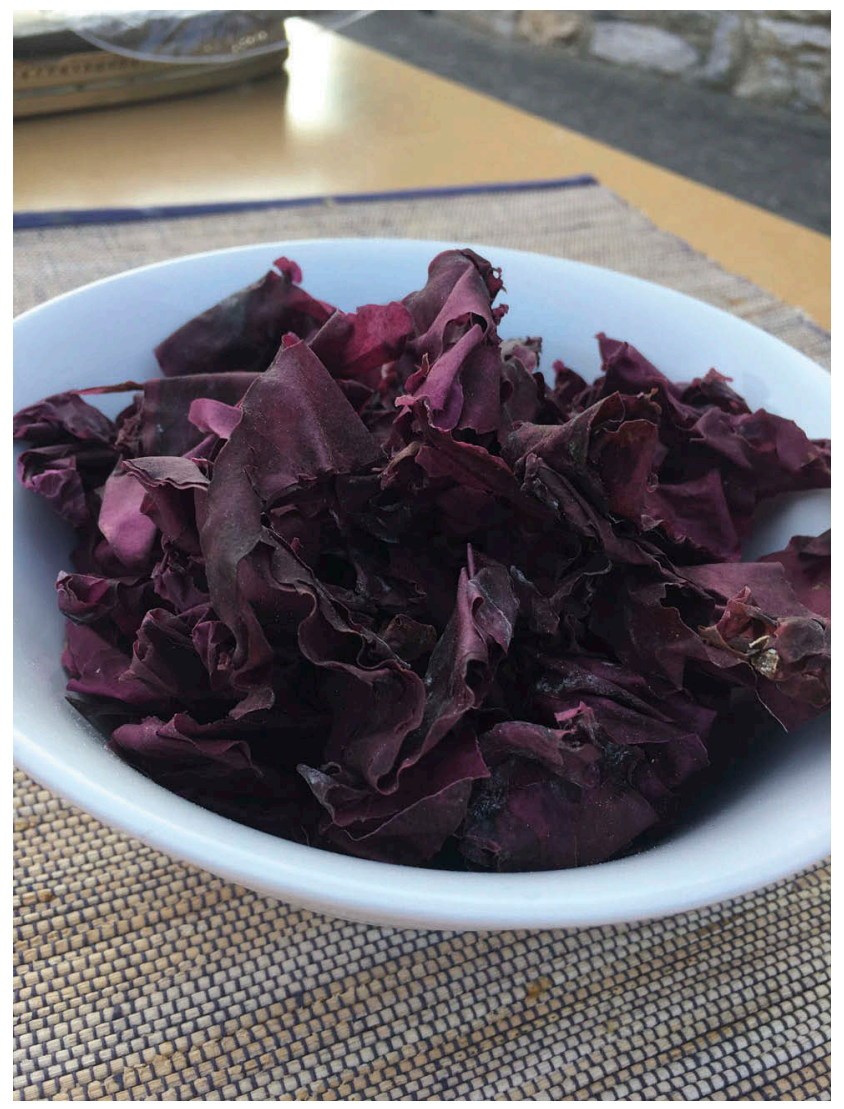

Figure 6. Duileasc - Dillisk - Dulse (Palmaria Palmata), edible seaweed popular in Ireland.

development of this new aesthetic and an emerging pool of talented Irish chefs compete successfully for international awards for their 'new Irish cooking. ${ }^{87}$ In 2010 , food finally became recognized as intangible cultural heritage by UNESCO (see Table 1). The Gastronomic meal of the French, gingerbread craft from Northern Croatia, and traditional Mexican cuisine were the first to appear but have been joined in subsequent years by food traditions from around the world ranging from Kimchi (Korea) to Nsima (Malawi). ${ }^{88}$ Italian food traditions have been mentioned in this paper, yet the first appearance on the UNESCO list of an Italian food tradition was 2017, the same year as Ireland's Uillean piping tradition was recognized.

This paper has identified some reasons why Ireland lags behind many of its European neighbours in safeguarding our traditional foods with PDO's and PGI's. Irish people are renowned throughout the world for their hospitality, and Colman Andrews highlights that the Irish are more deeply rooted to the land than even the Italians; but unlike Italians whose 'campanalismo' is rooted in identifying with the food of their local village, parish or region, in Ireland that local pride and identity is reserved for our GAA sports clubs, where we identify first with local club, then county, then country. That is not to say we don't have a food culture. Food marks the annual Irish festivities and traditions of Christmas (goose, turkey and ham, spiced beef, pudding, 


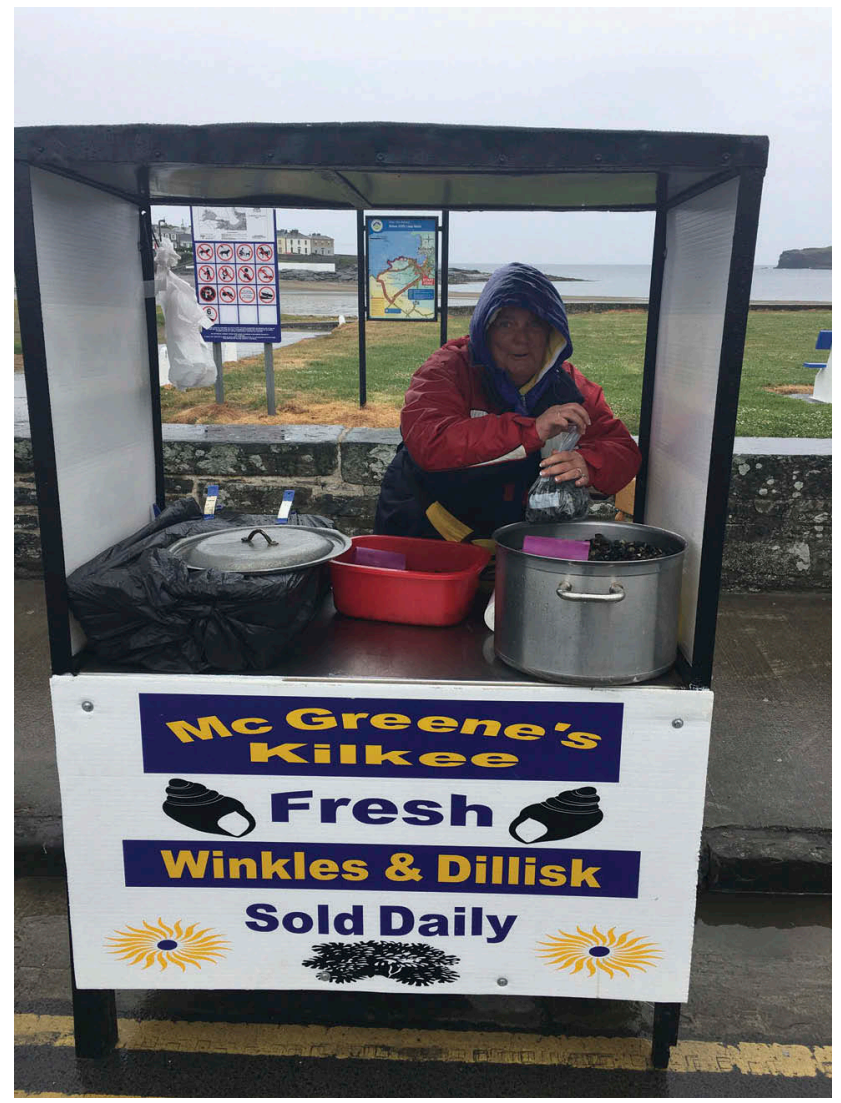

Figure 7. Periwinkle Traders, Kilkee, Co. Clare, May 2017.

mince pies and Christmas cake); Lent (pancakes, fasting, fish); Easter (roast lamb, Easter eggs, hot cross buns); Summer (new potatoes, wild salmon, mackerel and herrings, strawberries and blackberries); not to forget the Michaelmas goose, Martinmas beef, and Halloween food traditions (barm brack, apples and nuts, colcannon). Even within the modern fast food culture, some dishes, such as spice bags and curry chips are uniquely Irish. Coddle is still associated with Dublin and Drisheen with Cork. Boxty is more regularly available in the north-west Counties and Blaa has been recognized by the EU as coming from Waterford.

From place-names to mythology, storytelling, poetry and songs, food and hospitality is a vibrant theme that runs through Ireland's past. However, when the topic of food is discussed within the historiography of Ireland, the focus tends to be on the consequences of the Great Irish Famine (1845-52). Darra Goldstein points out that Ireland has suffered twice for its famines and food shortages: 'first due to very real deprivations; and second because these deprivations present an obstacle to the exploration of Irish food. All too often the story begins and ends with potatoes or famine. ${ }^{89}$ Another obstacle to the exploration of Irish food has been the focus on high politics rather than the 'histoire des mentalités' and the lack of engagement with sources in the Irish language by historians in the past. Tradition was left to the folklorists and often 
disseminated via the oral tradition. Much of this oral tradition (stories, songs, etc.) was documented for the first time during the Celtic revival in the last decades of the 19th century. Fionnbarra Ó Brolcháin highlights the creativity in literature, art, theatre and the academy that emerged during the Celtic revival when people embraced their heritage and used it to inspire dynamism. ${ }^{90}$ Ó Brolcháin argues cogently that Ireland's Gaelic heritage gives it a unique competitive advantage in this new age of innovation and creativity. He notes that bilingualism, or indeed, as with many Nordic countries - multilingualism is an advantage, noting that ironically, despite being an English speaking country in the latter half of the 19th century, this did not advantage us in competing with the Danish for England's butter market.

It could be argued that we are approaching a 'Celtic' food revival, with a flowering of award winning Irish chefs, restaurants and artisan food producers drawing inspiration from the new Nordic food aesthetic by engaging with and re-imagining their indigenous food culture and traditions. Equally there is a palpable rise in academic interest in Irish food history and tradition. Recent research clearly demonstrates that Ireland's culinary culture is much more nuanced than was previously understood. ${ }^{91}$ This paper argues that knowing and embracing our food heritage in the new millennium can give us competitive advantage and a unique selling point. Whether this manifests itself in promoting Irish food abroad or in increasing food tourism in Ireland, engaging and celebrating our food stories enable us to provide and enjoy more authentic food experiences and to also safeguard our intangible cultural food heritage for the next generations. This paper calls on Irish folklorists to identify and document the lesser known food traditions that are at risk of disappearing, such as the Ballach Bui of Connemara and the Aran Islands or the periwinkle traders of Kilkee, County Clare. It calls on food writers, scholars, chefs, educators and government agencies to recognize and celebrate food as part of Ireland's intangible cultural heritage.

\section{Notes}

1. Joep Leerssen, 'From Whiskey to Famine: Food and Intercultural Encounters in Irish History,' in Food, Drink and Identity in Europe, ed. by Thomas Wilson (Amsterdam: Rodopi, 2006), 49.

2. Claude Lévi-Strauss, Le cru et le cuit (Paris: Plon, 1964).

3. Richard Wrangham, Catching Fire: How Cooking made us Human (London: Profile Books, 2009).

4. https:/www.agriculture.gov.ie/media/migration/foodindustrydevelopmenttrademarkets/ a gri - foodand the economy/foodwise 2025 / s te pstosuccess 2017 / DAFMStepstoSuccess2017FINAL030717.pdf [accessed 14 November 2017].

5. http://www.failteireland.ie/FailteIreland/media/WebsiteStructure/Documents/ Publications/FI-Food-Strategy-Document.pdf, p.4. [accessed 23 March 2018].

6. A.T. Lucas, 'Irish Food before the Potato', Gwerin: A Half Yearly Journal of Folk Life 3:2 (1960) p.8; Lucas's findings were re-examined in 2013 in light of more recent research and found to be extremely robust, see Liam Downey and Ingelise Stuijts, 'Overview of historical Irish food products - A.T. Lucas (1960-2) revisited' The Journal of Irish Archaeology 22 (2013), pp. 111-126.

7. Colman Andrews, The Country Cooking of Ireland (San Francisco: Chronicle Books, 2009) 19. 
8. Kevin Myers, 'An Irishman's Diary'. The Irish Times, 7 February 2002; for discussion on how Bord Fáilte advertised to the French tourist market that Ireland was renowned for its food ingredients but not necessarily its cooking see Marjorie Deleuze, 'La Dimension Identitaire des Pratiques, des Habitudes et des Symboliques Alimentaires de l'Irlande Contemporaine.' (PhD diss., Université de Lille III, 2015).

9. Mark Moriarty, 'Anatomy of an Award-Winning Irish Dish: Celeriac baked in barley and fermented hay, hazelnut, celeriac, and smoked hay tea', Canadian Journal of Irish Studies, 41(2018), 33-53; Máirtín Mac Con Iomaire, 'Contextualizing the Irish Food Renaissance,' Canadian Journal of Irish Studies, 41(2018), 58-73; Máirtín Mac Con Iomaire, 'Haute Cuisine Restaurants in Nineteenth and Twentieth Century Ireland,' Proceedings of the Royal Irish Academy: Archaeology, Culture, History, Literature 115C (2015): 371-403.

10. Regina Sexton, 'Ireland: Simplicity and Integration, Continuity and Change.' In Culinary Cultures of Europe: Identity, Diversity and Dialogue, edited by Darra Goldstein, Kathrin Merkle, Fabio Parasecoli, and Stephen Mennell. 227-240. (Strasbourg: Council of Europe, 2005); Máirtín Mac Con Iomaire and Pádraic Óg Gallagher. 'The Potato in Irish Cuisine and Culture,' Journal of Culinary Science and Technology. 7, No.2-3(2009): 152-167; Máirtín Mac Con Iomaire and Pádraic Óg Gallagher, 'Irish Corned Beef: A Culinary History.' Journal of Culinary Science \& Technology 9, No. 1(2011), 27-43; Máirtín Mac Con Iomaire, 'The Changing Geography and Fortunes of Dublin's Haute Cuisine Restaurants 1958-2008', Food Culture \& Society 14, No. 4(2011), 525-545; Helen O'Connell, “'A Raking Pot of Tea”: Consumption and Excess in Early NineteenthCentury Ireland.' Literature \& History, 21, No. 2(2012); Máirtín Mac Con Iomaire, 'Public Dining in Dublin: The History and Evolution of Gastronomy and Commercial Dining 1700-1900'. International Journal of Contemporary Hospitality Management 25, No. 2(2013), 227-246; Susan Flavin, Consumption and Culture in Sixteenth-Century Ireland. (Woodbridge, Suffolk: Boydell Press, 2014); Máirtín Mac Con Iomaire and Eamon Maher, eds., 'Tickling the Palate': Gastronomy in Irish Literature and Culture (New York: Peter Lang, 2014); Madeline Shanahan, Manuscript Recipe Books as Archeological Objects: Food and Text in the Early Modern World (Maryland: Lexington Books, 2014); Rhona Richman-Kenneally, 'Tastes of Home in Mid-Twentieth-Century Ireland: Food, Design, and the Refrigerator'. Food and Foodways. 23, No. 1-2(2015), 80-103; Dorothy Cashman, 'An Investigation of Irish Culinary History through Manuscript Cookbooks, with Particular Reference to the Gentry of County Kilkenny (1714-1830)' (PhD diss., Dublin Institute of Technology, 2016); Elizabeth FitzPatrick and James Kelly, eds., Food and Drink in Ireland (Dublin: Royal Irish Academy, 2016); James Kelly, Food Rioting in Ireland in the Eighteenth and Nineteenth Centuries: The 'Moral Economy' and the Irish Crowd (Dublin: Four Courts Press, 2017); Canadian Journal of Irish Studies (The Food Issue) 41 (2018); Marzena Keating and Máirtín Mac Con Iomaire, 'Tradition and Novelty: Food Representations in Irish Women's Magazines 1922-1973.' Food, Culture and Society 21, No.4 (2018); See also the work of Caitrína Clear, for example, Caitríona Clear, Women of the House: Women's Household Work in Ireland, 1922-1961: Discourses, Experiences, Memories (Dublin: Irish Academic Press, 2000); “'We Will Again, Please God”: Maura Laverty, Irish Tradition, and Optimism,' in The Past in the Present: A Multidisciplinary Approach, ed. Fabio Mugnaini, Padraig O Healai, and Tok Freeland Thompson (Esch-sur- Alzette, LU: editpress, 2006), 41-52.

11. Voltaire is reputed to have said that in England 'they have sixty different religions but only one sauce'. Tallyrand was a little more generous noting that 'England has three sauces and three hundred and sixty religions, whereas France has three religions and three hundred and sixty sauces' http://www.foodreference.com/html/qsauces.html [accessed 23 June 2017].

12. Fionnbarra Ó Brolcháin, Meon Gaelach, Aigne Nuálaíoch (Baile Átha Cliath: Coiscéim, 2011).

13. Vincent Morley, The Popular Mind in Eighteenth-century Ireland. (Cork: Cork University Press, 2017), p.2. 
14. Declan Kiberd, 'The Popular Mind in Eighteenth-century Ireland review: An elegant and luminous study'. The Irish Times (15 April 2017) https://www.irishtimes.com/culture/ books/the-popular-mind-in-eighteenth-century-ireland-review-an-elegant-and-luminousstudy-1.3032259 [accessed 15 April 2017].

15. Oxford English Dictionary, 'Heritage' https://premium.oxforddictionaries.com/definition/ english/heritage [accessed 11 May 2017].

16. 'Dexter Beef makes first appearance on shelves' Irish Examiner, 4 October 2017, https:// www.pressreader.com/ireland/irish-examiner/20171004/282230895897207 [accessed 10 May 2018].

17. Conor Pope, 'Great Famine spud returns after almost 170 years' The Irish Times, 2 March 2013, https://www.irishtimes.com/news/great-famine-spud-returns-after-almost-170years-1.1316621 [accessed 10 May 2018]; Diarmuid Ó Giolláin, An Dúchas agus an Domhan, (Cork: Cork University Press, 2005), p.135.

18. A European system for the protection of the geographical names of certain foodstuffs (which have a tangible link to the geographical area after which they are named) was established by Council Regulation 1151/2012. Protection under the system is absolute and extends to translations of the name, evocation, misuse or imitation. Regulation $1151 / 2012$, and related Regulations 664/2012 and 668/2012, were given effect in Ireland by the European Union (Quality Schemes for Agricultural Products and Foodstuffs Regulations) 2015 [S.I. No. 296 of 2015] . PDO (Protected Designation of Origin) for products with a strong link to the defined geographical area where they are produced, whereas PGI (Protected Geographical Indication) for agricultural products and foods linked to a geographical area where at least one production step has taken place. See https://www.agriculture.gov.ie/gi/pdopgitsg-protectedfoodnames/ [accessed 11 May 2017].

19. UNESCO http://whc.unesco.org/en/statesparties/ie [accessed 14 May 2017].

20. Richard Kurin, 'Safeguarding Intangible Cultural Heritage in the 2003 UNESCO Convention: a critical appraisal'. Museum International. 56 (2004): 66-77. doi:10.1111/ j.1350-0775.2004.00459.x.

21. UNESCO https://ich.unesco.org/en/proclamation-of-masterpieces-00103 [accessed 14 May 2017].

22. UNESCO https://ich.unesco.org/en/RL/uilleann-piping-01264 [accessed 2 February 2018].

23. Department of Agriculture, Fisheries and the Marine https://www.agriculture.gov.ie/gi/ pdopgitsg-protectedfoodnames/ [accessed 11 May 2017].

24. see Regulation (EC) No 110/2008.

25. Andrews, Country Cooking, p. 19.; For descriptions of multiple course Irish State Banquets, see Elaine Mahon, 'Irish Cuisine: Irish Diplomatic Dining,' Canadian Journal of Irish Studies, 41 (2018), 124-155.

26. Arjun Appadurai, 'How to Make a National Cuisine: Cookbooks in Contemporary India,' Comparative Studies in Society and History 30, no.1 (1988), 3-24; Sidney W. Mintz, 'Cuisine: High, Low, and Not at All,' in Tasting Food, Tasting Freedom: Excursions into Eating, Culture, and the Past (Boston: Beacon Press, 1996); Jeffrey M. Pilcher, 'Tamales or Timbales: Cuisine and the Formation of Mexican National Identity, 1821-1911, The Americas, Vol. 53, No.2 (1996), 193-216; Rhona Richman Kenneally, " "There is a Canadian cuisine, and it is unique in all the world": Crafting National Food Culture During the Long 1960s,' in What's to Eat?: Entrées in Canadian Food History, ed. Nathalie Cooke (Montreal and Kingston: McGill Queen's University, 2009), 167-96; Rhona Richman Kenneally, “The greatest Dining extravaganza in Canada's history': Food, Nationalism, and Authenticity at Expo $67^{\prime}$ in Expo 67: Not Just a Souvenir, ed. Rhona Richman Kenneally and Johanne Sloane (Toronto: University of Toronto Press, 2009), 27-46; Richard Tellstrom, Inga-Britt Gustafsson, and Hakan Lindgren, 'Constructed National Food and Meal Archetypes at International Exhibitions from Paris 1867 to Aichi 2005,' National Identities 10, no.3 (2008), 313-27; Krishnendu Ray, 'Nation and Cuisine: The Evidence from American Newspapers ca. 1830-2003,' Food and Foodways 16, 
no.4 (2008), 259-97; Yael Raviv, 'National Identity on a Plate,' Palestine-Israel Journal of Politics, Economics and Culture, no. 8.4/9.1 (2002), 164-72; Rachel Laudan, Cuisine and Empire: Cooking in World History (Berkeley: University of California Press, 2013).

27. Gillian Riley, The Oxford Companion to Italian Food (Oxford: Oxford University Press, 2007).

28. Stemming from 'campanile' or 'bell tower' it refers to the area surrounding your village where you can hear the bell from. See https://ilcampanilismo.wordpress.com/2014/10/11/ the-concept-of-campanilismo/ [accessed 11 May 2017].

29. Laudan, Cuisine and Empire.

30. Lara Anderson, Cooking up the Nation: Spanish Culinary Texts and Culinary Nationalization in the Late Nineteenth and Early Twentieth Century. (Woodbridge: Tamesis, 2013); Carol Gold, Danish Cookbooks: Domesticity and National Identity 1616-1901. (Seattle: University of Washington Press, 2007).

31. Máirtín Mac Con Iomaire, 'The Emergence, Development and Influence of French Haute Cuisine on Public Dining in Dublin Restaurants, 1900-2000: An Oral History.' (PhD diss., Dublin Institute of Technology, 2009).

32. Marjorie Deleuze, “'Well, we didn't pass a bit o' remarks on it. It was second nature to us": The Rituals of Fasting in Ireland before Vatican II' Canadian Journal of Irish Studies 41 (2018), 226-249.

33. Leg of Mutton roasted in the Irish style; To garnish a duck in the Irish style; To prepare a peeled head of veal in the Irish style.

34. Lancelot De Casteau, Ouverture de cuisine. (Liege: Leonard Streel, 1604), pp. 116, 128, 130; Cashman, 'An Investigation', p.73; Máirtin Mac Con Iomaire, 'The Influence of French Travellers on Irish Gastronomy' in eds. Frank Healy and Brigitte Bastiat, Voyages Between France and Ireland: Culture, Tourism and Sport (Oxford: Peter Lang, 2017), pp.159-160.

35. Máirtín Mac Con Iomaire, and Tara Kellaghan, 'Royal Pomp: viceregal celebrations in Georgian Dublin' in Saberi, H. (ed) Celebrations, (Devon: Prospect Books, 2012).

36. Appadurai, 'How to make a National Cuisine'.

37. Cashman, 'An Investigation', p.225.

38. Appadurai, 'How to make a National Cuisine', pp.3-4.

39. Appadurai, 'How to make a National Cuisine', p.11.

40. Cashman, 'An Investigation', p. 7.

41. Myrtle Allen opened the Yeats Room in Ballymaloe House in June 1964 and became an award winning chef and restaurateur. She is one of most influential and culturally significant people in the story of Irish food in the last fifty years. See https://vimeo.com/ 73151483 [accessed 16 May 2017].

42. Máirtín Mac Con Iomaire and Dorothy Cashman. 2011. 'Irish Culinary Manuscripts and Printed Cookbooks: A Discussion.’ Petits Propos Culinaires 94(2011): 81-101.

43. Department of Agriculture Cookery Notes, (Dublin: Stationery Office, 1922); K.E. Warren, The Tailteann Cookbook (Dublin: W.M. Warren \& Sons, 1935); Florence Irwin, Irish Country Recipes (Belfast: The Northern Whig, 1937); Maura Laverty, Flour Economy (Dublin: Brown \& Nolan, 1941); Maura Laverty, Kind Cooking (Tralee: The Kerryman, 1946); Josephine Marnell, Nora Breathnach, Ann Martin, and Mor Murnaghan. All in the Cooking: Coláiste Mhuire Book of Household Cookery (Dublin: Educational Co. of Ireland, 1946).

44. Morley, The Popular Mind, p.71.

45. https://www.ria.ie/library/catalogues/special-collections/medieval-and-early-modern-manu scripts/foras-feasa-ar-eirinn [accessed 14 May 2017].

46. Kiberd, 'Popular Mind Review'; Morley,The Popular Mind, pp.106-110.

47. Fergus Kelly, Early Irish Farming. (Dublin; DIAS, 1997), p.346.

48. See Diarmuid Ó Giolláin 'Celebrations and the Rituals of Life' in The Cambridge Social History of Modern Ireland, eds. Eugenio F. Biagini and Mary E. Daly (Cambridge: Cambridge University Press, 2017), pp.297-311. O Giolláín draws on evidence from the 
Irish Folklore Commission and from writers such as Amhlaoibh Ó Súilleabháin, Sir William Wilde and Hugh Dorian.

49. Deleuze, 'Well, we didn't pass a bit o' remarks on it'; See http://w2.vatican.va/content/paulvi/en/apost_constitutions/documents/hf_p-vi_apc_19660217_paenitemini.html [accessed 4 April 2018].

50. Cashman, 'An Investigation', p.7; Tom Jaine, 'The English Kitchen,' in The English Kitchen: Historical Essays, ed. Eileen White (Totnes: Prospect Books, 2007), p.11.

51. Maura Laverty, Never No More. (London and New York: Longmans, Green and Co., 1947 [1942]), p.109.

52. Máirtín Mac Con Iomaire, 'Exploring the "Food Motif” in Songs from the Irish Tradition.' Paper presented at the Dublin Gastronomy Symposium, Dublin, 3 June 2014. http://arrow. dit.ie/cgi/viewcontent.cgi?article=1043\&context=dgs. [accessed 14 May 2017]; Máirtín Mac Con Iomaire, 'The Food Trope in Literature, Poetry and Songs from the Irish Tradition' in Piatti-Farnell and Lee Brien (eds.) The Routledge Companion to Literature and Food. (New York: Routledge, 2018), pp.364-378.; Theodora Fitzgibbon, A Taste of Ireland: Irish Traditional Food (London: J.M. Dent \& Sons, 1968).

53. On ginger and caraway flavour principle, see Mary F. Wack, 'Recipe-Collecting, Embodied Imagination, and Transatlantic Connections in an Irish Emigrant's Cooking,' Canadian Journal of Irish Studies, 41(2018), 100-123, 113; for discussion on gingerbread including its depiction by Hugh Douglas Hamilton in his Cries of Dublin and in Humphrey O' Sullivan's diary, see Dorothy Cashman, 'Sugar Bakers and Confectioners in Georgian Ireland,' Canadian Journal of Irish Studies, 41(2018), 74-99.

54. Although perhaps not the most objective research, it is of interest to the argument being made; See Patricia Murphy, 'Half of Irish people sneak sausages into their suitcase before boarding a plane' (1 April 2015) http://www.independent.ie/life/food-drink/food-news/ half-of-irish-people-sneak-sausages-into-their-suitcase-before-boarding-a-plane-31111430. html [accessed 10 May 2017].

55. Cathal Cowan and Regina Sexton, Ireland's Traditional Foods: An Exploration of Irish Local and Typical Foods and Drinks. (Dublin: Teagasc, The National Food Centre, 1997).

56. Bord Bia, 'What Ireland Ate Last Night' - A study into last night's evening meal(November 2011) http://www.bordbia.ie/industry/manufacturers/insight/publications/bbre ports/Documents/What\%20Ireland\%20Ate\%20Last\%20Night\%20-\%20Full\%20Report.pdf [accessed 11 May 2017].

57. Myers, 'Irishman's Diary'; Dennis Cotter in the introduction to The Café Paradiso Cookbook (Cork: Atrium, 1999) noted that Ireland did not have a culinary heritage and that we had a blank canvas to work with, but this assertion was removed from subsequent editions.

58. Hasia R. Diner, Hungering for America: Italian, Irish \& Jewish Foodways in the Age of Migration. (Cambridge, Mass.: Harvard University Press, 2003), pp. 84-5.

59. Mary E. L. Butler, 'Irishwomen and the home language' Gaelic League Pamphlet No. 6. See. digital.slv.vic.gov.au/dtl_publish/pdf/marc/26/2,617,171.html [accessed 14 May 2017].

60. Mac Con Iomaire, 'The Food Trope', p.371; Máirtín Mac Con Iomaire and Eamon Maher, eds. 'Tickling the Palate': Gastronomy in Irish Literature and Culture. (Oxford, UK: Peter Lang, 2014), p.3; Another rich example, courtesy of Lillis Ó Laoire, is the Irish song 'Fial Athair Dónall' which follows the Aislinge Meic Con Glinne tradition of describing a magic land made of food and drink, http://songsinirish.com/an-fial-athair-donall-lyrics/ [accessed 9 May 2018].

61. Katharine Simms, 1978. 'Guesting and Feasting in Gaelic Society.' Journal of Royal Society of Antiquaries of Ireland 108(1978): 67-100.

62. Tomás de Bhaldraithe, Cín Lae Amhlaoibh. (Baile Átha Cliath: An Clóchomhar Tta., 1970); Marie-Louise Legge, ed. The Diary of Nicholas Peacock 1740-1751. (Dublin: Four Courts Press, 2005); Marie-Louise Legge, ed., Synge Letters: Bishop Edward Synge to His Daughter Alicia. Roscommon to Dublin 1746-1752 (Dublin: Lilliput Press, 1996); Dorothea Herbert, 
Retrospections. (Dublin: Town House, 2004 [1929]); John Gamble, Society and Manners in Early Nineteenth-Century Ireland, ed. Breandán Mac Suibhne (Dublin: Field Day, 2011).

63. Kerby Miller, Review of Society and manners in early nineteenth century Ireland, by John Gamble, edited by Breandán MacSuibhne. History Ireland, 20, No. 1 (2012). http://www. historyireland.com/18th-19th-century-history/society-and-manners-in-early-nineteenthcentury-ireland/ [accessed 15 May 2017].

64. The first general Irish history book to include two chapters on food and diet was Louis M. Cullen, The Emergence of Modern Ireland, 1600-1900 (London: Batsford Academic and Educational, 1981), ch. 7 and 8; Other early food history books include Regina Sexton, $A$ Little History of Irish Food (London: Kyle Cathie, 1998); Leslie A. Clarkson and E. Margaret Crawford, Feast and Famine: Food and Nutrition in Ireland, 1500-1920 (Oxford: Oxford University Press, 2001).

65. Henry H. Glassie, Passing the Time in Ballymenone: Culture and History of an Ulster Community (Philadelphia: University of Pennsylvania Press, 1982); Kevin Danaher, Hearth and Stool and All!: Irish Rural Households (Dublin: Mercier Press, 1985). The Irish Folklore Collection at University College Dublin has comprehensive holdings of Danaher's work. Brid Mahon, Land of Milk and Honey: The Story of Traditional Irish Food \& Drink (Swords, Co. Dublin: Poolbeg Press, 1991); Patricia Lysaght, 'Bealtaine: Women, Milk, and Magic at the Boundary Festival of May,' in Milk and Milk Products from Medieval to Modern Times, ed. Patricia Lysaght (Edinburgh: Canongate Academic, 1994), 208-29; Patricia Lysaght, 'Food-Provision Strategies on the Great Blasket Island: Sea-Bird Fowling,' in Food from Nature: Attitudes, Strategies and Culinary Practices, ed. Patricia Lysaght (Uppsala: Royal Gustavus Adolphus Academy for Swedish Folk Culture, 2000), 333-63; Patricia Lysaght, 'Seabirds and their Eggs,' in Encylopedia of Food and Culture, ed. S. H. Katz (New York: Scribner, 2003), 3:243-45.

66. Morley, The Popular Mind, p.1.

67. Kiberd, 'Popular Mind Review'; Morley, The Popular Mind, p.9.

68. Mac Con Iomaire and Maher, 'Tickling the Palate'; Elizabeth FitzPatrick and James Kelly, Food and Drink in Ireland; Cashman, 'An Investigation'; Elaine Mahon, 'Setting the Irish State Table,' Feast Journal, no. 2 (October 2016), http://feastjournal.co.uk/article/settingthe-irish-state-table/ [accessed 4 November 2017]; The Canadian Journal of Irish Studies 41 (The Food Issue).

69. Patricia Lysaght, “'When I makes Tea, I makes Tea ...”:Innovation in Food - the Case of Tea in Ireland,' Ulster Folklife 33 (1987)53-71; Cormac Ó Gráda, An Drochshaol: Béaloideas agus Amhráin. (Baile Átha Cliath: Coiscéim, 1994); Máirtín Mac Con Iomaire,'Gastro-Topography: Exploring Food-Related Place Names in Ireland.' Canadian Journal of Irish Studies 38, No.1/2(2014): 126-157; Mac Con Iomaire, 'Exploring'; Mac Con Iomaire, 'The Food Trope'.

70. Dinnseanchas is a class of onomastic text in early Irish literature, recounting the origins of place-names and traditions concerning events and characters associated with the places in question. Dinnseanchas stories are also incorporated into saga texts such as Táin Bó Cúailnge and Acallam na Senórach. See Mac Con Iomaire, 'The Food Trope'.

71. Cathal Ó Háinle, 'Notitiae: 4. Pléaráca na Ruarcach.' Éigse 17, No. 2 (1977): 228-235.

72. Laudan, Cuisine and Empire.

73. https://www.logainm.ie/ga/1394256?s. [accessed 3 May 2018].

74. Mac Con Iomaire, 'Gastro-Topography: Exploring Food Related Place Names in Ireland'; Máirtín Mac Con Iomaire, 'The Gastro-Topography and Built Heritage of Dublin, Ireland' In Food and Architecture at the table, ed. by Samantha L. Martin McAuliffe, pp.73-93. (London: Bloomsbury Academic, 2016).

75. Sean Ó Tuama and Thomas Kinsella, eds. An Duanaire: An Irish Anthology: 1600-1900: Poems of the Dispossessed. (Philadelphia: Pennsylvania University Press, 1981).

76. See Colm Ó Coigligh, Raiftearaí: Amhráin agus Dánta. (Baile Átha Cliath: An Clóchomhar, 1987). 
77. For a rich source of the role of poets at the wedding feast in Ireland see Margo GriffinWilson, The Wedding Poems of Daibhí Ó Bruadair (Dublin: Dublin Institute of Advanced Studies, 2010).

78. Ó Coigligh, Raiftearaí, pp.110-114.

79. Gearóid Ó hAllmhuráin, “Amhrán an Ghorta”: The Great Famine and Irish Traditional Music' New Hibernia Review / Iris Éireannach Nua 3, No. 1 (1999): 19-44.

80. Micheál Briody, The Irish Folklore Commission 1935-1970 (Helsinki: Finnish Literature Society, 2007), p.20; The Schools Collection of Folklore is available online at www.duchas.ie.

81. For such claims see Daniel Corkery, The Hidden Ireland (Dublin: M.H. Gill and Son, 1956), p.10; Morley, The Popular Mind, p. 2 highlights that 'there is no factual basis for Corkery's claims that a middle class did not exist in eighteenth-century Munster'.

82. de Bhaldraithe, Cin Lae Amhlaoibh, xxx. 'Tá cuntas inti ar bhéili breátha an duine mheándeisiúil a bhréagnionn an té a deir nach raibh éagsúlacht beatha is oiliúnt in ealaín na cócaireachta ag na Gaeilgeoirí.'

83. Leerssen, 'From Whiskey to Famine: Food and Intercultural Encounters in Irish History,'.

84. Krishnendu Ray, The Ethnic Restaurateur (London: Bloomsbury Academic, 2016), p. 97.

85. See www.failteireland.ie [accessed 3 April 2018].

86. William Wilde, 'The Food of the Irish,' Dublin University Magazine, February 1854, 127-146; Helen O'Connell, 'Bleak Food: William Wilde, Famine, and Gastronomy,' Canadian Journal of Irish Studies, 41(2018), p.159.

87. Mac Con Iomaire, 'Contextualizing the Irish Food Renaissance'.

88. UNESCO http://www.unesco.org/culture/ich/en/lists [accessed 11 May 2017].

89. Darra Goldstein, 'Foreword'. In 'Tickling the Palate': Gastronomy in Irish Literature and Culture, edited by Máirtín Mac Con Iomaire and Eamon Maher, xi-xvii. (Oxford: Peter Lang, 2014), p.xii.

90. Ó Brolcháin, Meon Gaelach, Aigne Nuálaíoch .

91. Cf. Wack, 'Recipe-Collecting, Embodied Imagination, and Transatlantic Connections in an Irish Emigrant's Cooking,'; Cashman, 'Sugar Bakers and Confectioners in Georgian Ireland,'; Mahon, 'Irish Cuisine: Irish Diplomatic Dining'.

\section{Disclosure statement}

No potential conflict of interest was reported by the author.

\section{Notes on contributor}

Dr. Máirtín Mac Con Iomaire is a senior lecturer in the School of Culinary Arts and Food Technology in the Dublin Institute of Technology (DIT), Ireland. He is the co-founder and chair of the biennial Dublin Gastronomy Symposium and is a trustee of the Oxford Symposium on Food and Cookery. He is chair of the Masters in Gastronomy and Food Studies in DIT, the first such programme in Ireland. $\mathrm{He}$ is co-editor with Eamon Maher of 'Tickling the Palate': Gastronomy in Irish Literature and Culture (Peter Lang: 2014), and with Rhona Richman Kenneally on 'The Food Issue' of The Canadian Journal of Irish Studies (2018). He has published widely in peer reviewed journals and is a regular contributor on food in the media. In 2018, he presented an eight part television series for TG4 called 'Blasta' celebrating Ireland's food heritage.

Email: mairtin.macconiomaire@dit.ie

\section{ORCID}

Máirtín Mac Con Iomaire (D) http://orcid.org/0000-0001-6622-3299 